\title{
The influence of non-normative fuel on its operational properties
}

Fuels that do not meet the requirements of quality standards cannot be used to power vehicle engines. The work involved physicochemical analyses of non-normative fuel and its effect on the operational properties of the powered vehicle. The research fuels were two gasolines, characterized by a reduced resistance to oxidation processes due to their long-term storage. The results were compared to the properties of conventional fuels that met all normative requirements. The studies have shown that the fuel slightly deviating from the standard parameters does not noticeably affect the useful properties of the vehicle.

Key words: non-normative fuels, long term storage, fuel aging, gasoline

\section{Introduction}

All UE countries are obligated to keep 90-day intervention stocks of crude oil as well as liquid fuels and 30-day intervention stocks of natural gas. In Poland, these requirements are regulated by the act from 2007 year on crude oil reserves, petroleum products and natural gas [1]. The increasing demand for gasoline and diesel oil causes that the strategic reserves of fuels also should increase. The fuels intended for storage and to later use of them in vehicles need to meet requirements regulated by the act on the system of monitoring and controlling the quality of fuels [2]. The quality requirements for gasoline are specified in the EN 228 standard and for diesel oil in the EN 590 one. The specifications for fuels are more and more restrictive, so the retention of their quality during long-term storage is problematic. During storage process the properties of fuels deteriorate as a results of changes occurring in their chemical structure. The changes are caused by different factors as: chemical composition, atmospheric conditions, presence of inhibitors or activators of oxidation reactions and type of the storage tank. The presence of oxygen and free radicals lead to autoxidation, polymerization and condensation of fuels compounds. As a result of these processes the gums are formed and the stability of fuels is decreased [6, 8, 9]. It is difficult to specify universal mechanism of oxidation of petroleum products and in the literature we can find many theories concern this process [4]. The reason of such situation is - among others - complex and different chemical structure and sensitivity to degradation processes of the fuels. Moreover, addition of biocomponents to the fuels (FAME to diesel and bioethanol to gasoline) accelerates oxidation and caused that these mechanism are different and more complex $[3,5,7]$. In order to minimize adverse phenomena during fuel storage, various types of additives are added at the stage of its production. The additives improve - among others - chemical stability, resistance to corrosion and growth of microorganisms as well as low temperature properties of fuels.

Fuels that do not meet all quality requirements must not be used to power vehicle engines. Under the current regulations, such fuels should be disposed as hazardous waste. For this reason, in the literature, there is no research on the impact of aged fuel after long-term storage on behavior of the vehicle. The authors of this paper conducted research to determine the influence of non-normative fuel on operational properties of the vehicle.

\section{The research object and methods}

Authors investigated the influence of non-normative fuel on the operational properties of vehicles. The tests were carried out at the Automotive Industry Institute (PIMOT) in Warsaw. The research materials were two fuels:

- 95 octane gasoline, containing up to $5 \%(\mathrm{v} / \mathrm{v})$ bioethanol (denoted as $\mathrm{Pb}$ 95),

- 98 octane gasoline, without bioethanol, containing about $12.6 \%$ (v/v) ETBE (denoted as Pb 98).

The physicochemical properties of tested gasolines according to the EN ISO 228 standard were performed before operational tests. The tests were carried out in the PIMOT Analytical Laboratory. Both gasolines did not meet the requirements for the existent gum content of fuel, as shown in Table 1. In terms of other fuel parameters, the tested gasolines met the requirements of the EN ISO 228 standard.

Table 1. Parameters that were not met by tested gasolines

\begin{tabular}{|l|c|c|c|}
\hline Parameter & Fuel & Test result & $\begin{array}{c}\text { Standard } \\
\text { requirements }\end{array}$ \\
\hline $\begin{array}{l}\text { The existent gum con- } \\
\text { tent [mg/100 ml] }\end{array}$ & $\mathrm{Pb} 95$ & 22 & $\max 5$ \\
\cline { 2 - 3 } & $\mathrm{Pb} 98$ & 20 & $\operatorname{man}$ \\
\hline
\end{tabular}

Operational tests were conducted in the PIMOT Vehicle Research Laboratory and in the PIMOT Vehicle Control Station. The following parameters were tested:

- fuel consumption and effective power of the engine, on the Schenk Komeg EMDY 48 chassis dynamometer,

- exhaust emissions from vehicle engine $\left(\mathrm{CO}, \mathrm{CO}_{2}, \mathrm{HC}\right.$, $\mathrm{NO}_{\mathrm{x}}$ ) at idle speed and at speed above idle, using the Capelec CAP 3201-4GAZ flue gas analyser,

- dynamic acceleration of the vehicle in the following speed ranges: $(0-100) \mathrm{km} / \mathrm{h},(60-100) \mathrm{km} / \mathrm{h}$ on the third gear and (80-120) $\mathrm{km} / \mathrm{h}$ on the fourth gear, using the RaceLogic device.

The tests were carried out for two years, on two selected vehicles, with spark ignition engines and with similar technical parameters, presented in Table 2 .

The obtained test results were compared with the results for the reference fuel, which was a commercial gasoline that met the requirements of the EN 228 standard. Addi- 
tionally, to check the influence of non-normative fuel on the lubricating oil properties, the samples of engine oil were tested during operational tests.

Table 2. Technical data for tested vehicles

\begin{tabular}{|l|c|c|}
\hline Parameter & Vehicle 1 & Vehicle 2 \\
\hline Brand & Skoda & Skoda \\
\hline Model & Octavia & Octavia \\
\hline Body styles & Sedan & Sedan \\
\hline Year of production & 2005 & 2005 \\
\hline Type of fuel & Gasoline & Gasoline \\
\hline Mileage $[\mathrm{km}]$ & 301887 & 279897 \\
\hline Engine capacity $\left[\mathrm{cm}^{3}\right]$ & 1781 & 1781 \\
\hline Nominal power of engine $[\mathrm{kW}]$ & 110 & 110 \\
\hline Top speed $[\mathrm{km} / \mathrm{h}]$ & 217 & 217 \\
\hline
\end{tabular}

Physical and chemical tests of the oil were carried out in the PIMOT Analytical Laboratory. The samples of lubricating oil were collected periodically during each engine oil change. The lubricating oil was changed after changing the test fuel. Changes in the properties of the oil were compared with the parameters of fresh oil and oil obtained after the reference fuel operational test. During operational tests the fully synthetic commercial engine $5 \mathrm{~W}-40$ class oil was used to lubricate the engines of both tested vehicles. The tested parameters of oil samples and used test methods are presented in Table 3.

Table 3. The tested parameters of oil samples and used test methods

\begin{tabular}{|l|c|}
\hline Parameter & Method \\
\hline Kinematic viscosity at temperature $100^{\circ} \mathrm{C}$ & EN ISO 3104 \\
\hline Kinematic viscosity at temperature $40^{\circ} \mathrm{C}$ & EN ISO 3104 \\
\hline Contamination content & Own method \\
\hline Fuel content & PN/C-04083 \\
\hline Carbon residue - Micro method & EN ISO 10370 \\
\hline $\begin{array}{l}\text { Flash point - Pensky-Martens closed cup } \\
\text { method }\end{array}$ & EN ISO 2719 \\
\hline
\end{tabular}

\section{Research results}

Table 4 presents the average results of the concentration of particular components of the exhaust gases, obtained from the vehicle 1, while in Table 5 from the test of vehicle 2 .

Table 4. Average concentration of the exhaust gases components from vehicle 1

\begin{tabular}{|c|c|c|c|c|c|c|c|}
\hline No. & $\begin{array}{c}\text { Type of } \\
\text { fuel }\end{array}$ & $\begin{array}{c}\text { Number of } \\
\text { kilometers }\end{array}$ & $\begin{array}{c}\mathrm{CO} \\
{[\% \mathrm{v} / \mathrm{v}]}\end{array}$ & $\begin{array}{c}\mathrm{CO}_{2} \\
{[\% \mathrm{v} / \mathrm{v}]}\end{array}$ & $\begin{array}{c}\mathrm{HC} \\
{[\mathrm{ppm} / \mathrm{v}]}\end{array}$ & $\begin{array}{c}\mathrm{NO}_{\mathrm{x}} \\
{[\mathrm{ppm} \mathrm{v} / \mathrm{v}]}\end{array}$ & $\lambda$ \\
\hline 0 & Reference & 15569 & 0.09 & 15.4 & 49.5 & 20.0 & 1.035 \\
\hline 1 & PB 95 & 16969 & 0.23 & 15.0 & 84.5 & 58.0 & 1.085 \\
\hline 2 & PB 95 & 19545 & 0.05 & 15.2 & 41.5 & 21.0 & 1.032 \\
\hline 3 & PB 95 & 23993 & 0.15 & 14.9 & 68.0 & 42.5 & 1.023 \\
\hline 4 & PB 95 & 26012 & 0.01 & 15.7 & 47.0 & 10.5 & 1.011 \\
\hline 5 & PB 95 & 27204 & 0.13 & 15.6 & 65.0 & 63.0 & 0.998 \\
\hline 6 & PB 95 & 30040 & 0.11 & 15.6 & 39.5 & 72.5 & 1.002 \\
\hline 7 & PB 95 & 31420 & 0.02 & 15.8 & 37.0 & 10.0 & 1.007 \\
\hline 8 & PB 98 & 33953 & 0.17 & 15.3 & 94.5 & 82.5 & 0.999 \\
\hline 9 & PB 98 & 36186 & 0.02 & 15.5 & 42.5 & 22.0 & 1.009 \\
\hline 10 & PB 98 & 44454 & 0.04 & 15.9 & 29.0 & 32.5 & 1.005 \\
\hline 11 & PB 98 & 46744 & 0.10 & 15.7 & 59.5 & 12.5 & 1.005 \\
\hline 12 & PB 98 & 48703 & 0.05 & 14.6 & 46.0 & 33.0 & 1.000 \\
\hline 13 & PB 98 & 51919 & 0.13 & 15.7 & 26.5 & 68.0 & 1.000 \\
\hline
\end{tabular}

The test results presented in Tables 4 and 5 indicated that there was no correlation between the concentration of exhaust components and the type of fuel used. Average concentrations of exhaust components were within following limits:

- CO: $(0.05-0.23) \% \mathrm{v} / \mathrm{v}$ for vehicle 1 and $(0.05-0.59) \%$ $\mathrm{v} / \mathrm{v}$ for vehicle 2 ,

- HC: (26.5-94.5) ppm for vehicle 1 and (10.0-90.5) ppm for vehicle 2 ,

- $\mathrm{NO}_{\mathrm{x}}$ : (10.0-82.5) ppm for vehicle 1 and (13.0-76.5) ppm for vehicle 2 .

Values of concentrations of exhaust gases components, recorded during supplying the engine with non-normative fuels, were within wide limits. Results of emission for the reference fuel also were within these limits. It has to be borne in mind, that the analyses for the reference fuel were carried out only once (prior to the commencement of operational tests). According to the Authors, it is likely that in the next test for reference fuel, the concentration of exhaust gases components would also be different (as in the case of non-normative fuels).

Table 5. Average concentration of the exhaust gases components from vehicle 2

\begin{tabular}{|c|c|c|c|c|c|c|c|}
\hline No. & Type of fuel & $\begin{array}{c}\text { Number } \\
\text { of kilome- } \\
\text { ters }\end{array}$ & $\begin{array}{c}\mathrm{CO} \\
{[\% \mathrm{v} / \mathrm{v}]}\end{array}$ & $\begin{array}{c}\mathrm{CO}_{2} \\
{[\% \mathrm{v} / \mathrm{v}]}\end{array}$ & $\begin{array}{c}\mathrm{HC} \\
{[\mathrm{ppm} \mathrm{v} / \mathrm{v}]}\end{array}$ & $\begin{array}{c}\mathrm{NO}_{\mathrm{x}} \\
{[\mathrm{ppm} \mathrm{v} / \mathrm{v}]}\end{array}$ & $\lambda$ \\
\hline 0 & Reference & 14884 & 0.32 & 14.7 & 39.0 & 31.0 & 1.060 \\
\hline 1 & PB 95 & 16111 & 0.06 & 15.5 & 24.5 & 40.0 & 1.030 \\
\hline 2 & PB 95 & 16796 & 0.08 & 15.6 & 20.0 & 22.5 & 1.060 \\
\hline 3 & PB 95 & 17907 & 0.37 & 14.2 & 28.5 & 76.5 & 1.035 \\
\hline 4 & PB 95 & 19011 & 0.29 & 13.7 & 36.5 & 53.0 & 1.024 \\
\hline 5 & PB 95 & 19831 & 0.59 & 13.9 & 18.5 & 13.0 & 1.060 \\
\hline 6 & PB 95 & 22060 & 0.12 & 15.6 & 10.0 & 15.0 & 1.007 \\
\hline 7 & PB 95 & 23785 & 0.10 & 15.5 & 17.0 & 23.5 & 1.015 \\
\hline 8 & PB 95 & 27993 & 0.08 & 15.5 & 46.5 & 13.5 & 1.008 \\
\hline 9 & PB 95 & 33207 & 0.32 & 14.7 & 15.0 & 70.0 & 1.008 \\
\hline 10 & PB 98 & 36118 & 0.17 & 15.3 & 47.0 & 16.0 & 1.028 \\
\hline 11 & PB 98 & 40625 & 0.09 & 15.6 & 52.0 & 28.0 & 1.013 \\
\hline 12 & PB 98 & 44613 & 0.12 & 15.7 & 13.0 & 29.5 & 1.010 \\
\hline 13 & PB 98 & 50697 & 0.05 & 15.7 & 90.5 & 28.0 & 1.010 \\
\hline
\end{tabular}

Data in Tables 4 and 5 also indicate differences in gas concentration values for the same fuel (reference or nonnormative) for different vehicles and for different measurement periods. These differences may be the result of many factors, including e.g.:

- age of the vehicle (over fourteen years old),

- setting of engine control parameters,

- variable climatic periods of tests conducting (different conditions of vehicle operation depending on the season),

- accuracy and sensitivity of used measuring device,

- measurement methods (location of the measuring probe),

- different chemical composition of fuels, which could have translated into the different course of the combustion process of fuels.

During the operational tests, the vehicles acceleration time also was measured. The average results of these mea- 
surements are presented on Fig. 1. On the base of research results concerning the vehicles acceleration time it has been stated that there is no significant influence of nonnormative fuels on that parameter. The vehicle acceleration times for both vehicles supplied with non-normative fuels were similar, for three different speed ranges and throughout the research period, to these measured for vehicles fuelled with reference fuels.

a)

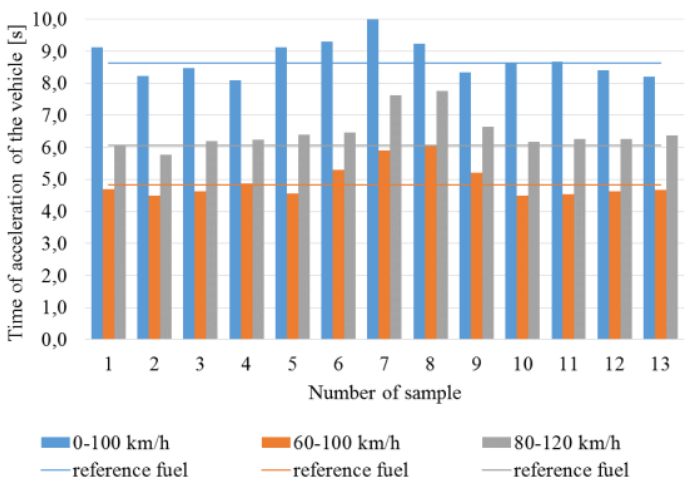

b)

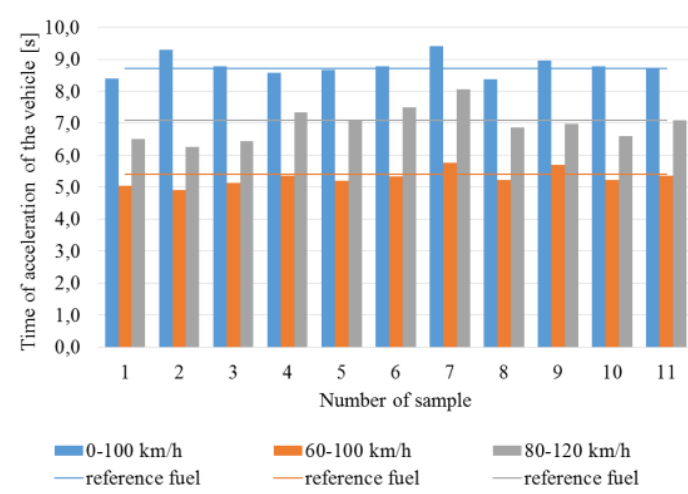

Fig. 1. Average acceleration time of vehicles for: a) vehicle 1, b) vehicle 2

Research results of physicochemical properties of engine oil samples collected during operational test are presented in Tables 6 and 7. Based on the obtained results, it was found that no significant changes in all tested parameters of lubricating oil occurred during operational tests of non-normative fuels in comparison to the reference fuels. Observed changes are typical for used lubricating oil. The samples of engine oil from both vehicles had lower viscosity and ignition temperature value, especially of in case of vehicle 2 , what was caused by presence of fuel entered the lubrication system. The content of contamination presented in all oil samples remained low and was at similar level like in fresh oil.

In comparison with fresh engine oil, we observed slight decrease in carbon residue value for all samples of oils after driving tests. This parameter describes the tendency of lubricating oil to form carbonaceous deposits under degradation conditions. The ability to form carbon residue is related to the chemical composition of the oil, especially to the presence of unsaturated, macromolecular chemical compounds. Slight deterioration of this parameter means that used during tests lubricating oil retains its protective properties for a long time and aging processes of oil occurring slow.

Table 6. Physicochemical properties of engine oil samples collected during operational test of vehicle

\begin{tabular}{|l|c|c|c|c|}
\hline Parameter & Fresh oil & \multicolumn{3}{|c|}{ Sample } \\
\hline Type of fuel & - & Reference & PB 95 & PB 98 \\
\hline $\mathrm{V} 100\left[\mathrm{~mm}^{2} / \mathrm{s}\right]$ & 13.50 & 12.12 & 12.40 & 12.16 \\
\hline $\mathrm{V} 40\left[\mathrm{~mm}^{2} / \mathrm{s}\right]$ & 84.02 & 77.86 & 82.13 & 78.16 \\
\hline $\begin{array}{l}\text { Contamination content } \\
{[\%, \mathrm{~m} / \mathrm{m}]}\end{array}$ & $<0.005$ & $<0.005$ & $<0.005$ & $<0.005$ \\
\hline Carbon residue $[\%, \mathrm{~m} / \mathrm{m}]$ & 1.14 & 1.68 & 1.68 & 1.82 \\
\hline Fuel content $[\%, \mathrm{v} / \mathrm{v}]$ & 0 & 2.4 & 2.0 & 1.8 \\
\hline Flash point $\left[{ }^{\circ} \mathrm{C}\right]$ & 240 & 193 & 230 & 240 \\
\hline
\end{tabular}

Table 7. Physicochemical properties of engine oil samples collected during operational test of vehicle 2

\begin{tabular}{|l|c|c|c|c|}
\hline Parameter & Fresh oil & \multicolumn{3}{|c|}{ Sample } \\
\hline Type of fuel & - & Reference & PB 95 & PB 98 \\
\hline $\mathrm{V} 100\left[\mathrm{~mm}^{2} / \mathrm{s}\right]$ & 13.50 & 13.22 & 13.07 & 12.55 \\
\hline $\mathrm{V} 40\left[\mathrm{~mm}^{2} / \mathrm{s}\right]$ & 84.02 & 83.70 & 80.92 & 78.41 \\
\hline $\begin{array}{l}\text { Contamination content } \\
{[\%, \mathrm{~m} / \mathrm{m}]}\end{array}$ & $<0.005$ & $<0.005$ & $<0.005$ & 0.005 \\
\hline Carbon residue $[\%, \mathrm{~m} / \mathrm{m}]$ & 1.14 & 1.86 & 1.86 & 1.74 \\
\hline Fuel content $[\%, \mathrm{v} / \mathrm{v}]$ & 0 & 1.6 & 1.4 & 1.4 \\
\hline Flash point $\left[{ }^{\circ} \mathrm{C}\right]$ & 240 & 222 & 236 & 232 \\
\hline
\end{tabular}

\section{Conclusions}

During two-year operational tests, vehicles fuelled with aged fuels has travelled an average of approximately 51,000 $\mathrm{km}$. During operational tests on a selected group of vehicles, no negative impact of the tested non-normative gasolines on the operational properties of vehicles was found. There were no observed:

- faults,

- problems connected with starting the engine,

- excessive smoke during start-up or heating up of engine,

- deterioration of the acceleration dynamics of tested vehicles

- deterioration of physicochemical properties of engine oil and its losses during operational test.

Performed tests have shown that fuel, which slightly deviates from the normative requirements, does not noticeably affect the useful properties of the vehicle.

\section{Nomenclature}

$\mathrm{CO}$ carbon monoxide

$\mathrm{CO}_{2} \quad$ carbon dioxide

EN European Norm International

ETBE ethyl tert-butyl ether

FAME fatty acid methyl esters

$\mathrm{HC}$ hydrocarbons (equivalent of hexane $\mathrm{C}_{6} \mathrm{H}_{14}$ )
ISO Organization for Standardization

$\mathrm{NO}_{\mathrm{X}} \quad$ nitrogen oxides

ON diesel oil

ON BIO diesel oil with FAME

$\mathrm{Pb} 95$ unleaded 95 octane gasoline

$\mathrm{Pb} 98$ unleaded 98 octane gasoline 


\section{Bibliography}

[1] Act of 16 February 2007 on stocks of crude oil, petroleum products and natural gas, the principles of proceeding in circumstances of a threat to the fuel security of the State and disruption on the petroleum market. Journal of Laws No. 52 item 343, with later changes.

[2] Act of 25 August 2006 on fuel quality monitoring and control system. Journal of Laws No. 169 item 1200, with later changes.

[3] CHRISTENSEN, E., MCCORMICK, R.L. Long-term storage stability of biodiesel and biodiesel blends. Fuel Processing Technology. 2014, 128, 339-348. DOI: 10.1016/ j.fuproc.2014.07.045.

[4] OWCZUK, M., KOŁODZIEJCZYK, K. Liquid fuel ageing processes in long-term storage conditions. Chapter in: Storage Stability of Fuels (edited by Biernat K.). InTech. 2015, 101-129. DOI: $10.5772 / 59799$.

Anna Matuszewska, DEng. - Department of Fuel and Bioeconomy, Automotive Industry Institute.

e-mail: a.matuszewska@pimot.eu

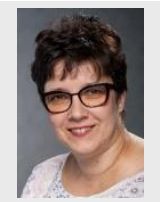

[5] PEREIRA, C.C., PASA, V.M.D. Effect of alcohol and copper content on the stability of automotive gasoline. Energy Fuels. 2005, 19, 426-432. DOI: 10.1021/ef049849h.

[6] RITA, C.C., PEREIRA, VÂNYA, M.D., PASA. Effect of mono-olefins and diolefins on the stability of automotive gasoline. Fuel. 2006, 85, 1860-1865, DOI: 10.1016/ j.fuel.2006.01.022.

[7] SALUJA, R.K., KUMAR, V., SHAM, R. Stability of biodiesel - a review. Renewable and Sustainable Energy Reviews. 2016, 62, 166-181. DOI: 10.1016/j.rser.2016.05.001.

[8] XIONG, Y., SU, P., ZHOU, J., QI, S. Research on the rate prediction model of diesel oxidation in storage. Chemical Engineering Transactions. 2016, 51, 115-120, DOI: 10.3303/ CET1651020.

[9] ZANIER, A. Thermal-oxidative stability of motor gasolines by pressure d.s.c. Fuel. 1998, 77, 865-870, DOI: 10.1016/ S0016-2361(97)00265-2.

Marlena Owczuk, DEng. - Department of Fuel and Bioeconomy, Automotive Industry Institute.

e-mail:m.owczuk@pimot.eu 